\title{
KETERKAITAN WUJUD DAN UNSUR KEBUDAYAAN PADA PEMBELAJARAN IPS
}

\author{
Raina Hapipah \\ Email: 2010128120005@mhs.ulm.ac.id \\ Program Studi Pendidikan IPS Fakultas Keguruan dan Ilmu Pendidikan \\ Universitas Lambung Mangkurat
}

Banjarmasin

\begin{abstract}
Abstrak
Pembelajaran berbasis kebudayaan seperti wujud kebudayaan dan unsur dari kebudayaan merupakan sebuah upaya untuk mengembangkan kearifan lokal disuatu bangsa. Selain itu, dengan adanya pembelajaran berbasis kebudayaan dilakukan agar para peserta didik dapat mengenalisis bagaimana kebudayaan yang positif dan bagaimana kebudayaan yang negatif serta peserta didik juga dapat mempertahankan bagaimana kebudayaan yang asli pada bangsanya. Dengan adanya pembelajaran mengenai kebudayaan berupa wujud kebudayaan dan unsur kebudayaan memiliki erat kaitannya dengan Pembelajaran IPS dilingkungan sekolah. Pada Antropologi, kebudayaan merupakan bagian dari Antropologi dan bersifat Universal. Adanya Kebudayaan akan membentuk watak dan dapat mengembangkan potensi diri pada peserta didik. Sumber pembelajaran berupa kebudayaan didapatkan peserta didik melalui pembelajaran IPS di sekolah maupun di lingkungan luar dari sekolah atau lingkungan masyarakat. Pembelajaran yang berbasis kebudayaan merupakan alat untuk memberikan pengetahuan berupa wujud kebudayaan dan unsur kebudayaan pada suatu bangsa kepada peserta diidk agar dikemudian hari mereka bisa menganalisis dan menjaga bagaimana kebudayaan yang sebenarnya.
\end{abstract}

Kata Kunci: Wujud Kebudayaan, Unsur kebudayaan, Pembelajaran IPS

\section{PENDAHULUAN}

Wujud kebudayaan adalah sebuah bentuk dari rangkaian tindakan dan aktifitas manusia atau masyarakat menjadi lebih berpola yang berupa kearifan lokal di suatu lingkungan masyarakat. Menurut J.J. Honigman dan Koentjaraningrat, Wujud Kebudayaan merupakan sebuah kompleks dari berbagai ide-ide, gagasan, nilai-nilai, norma-norma, dan peraturan yang ada di suatu lingkungan masyarakat. Kebudayaan memiliki sifat yang sesuai dengan wujud yang 
ada pada dasarnya dan masih berupa sesuatu yang bersifat abstrak (tidak dapat digambarkan secara nyata). Oleh karena itu, wujud kebudayaan yang ada pada lingkungan masyakarat sebagian juga masih merupakan sebuah kerangka pemikiran atau wacana yang ada pada pemikiran dari kalangan antropolog, sosiolog, dan lain sebagainya yang kemudian menyebut hal tersebut menjadi sebuah sistem budaya atau cultural system.

Unsur-unsur kebudayaan adalah strategi dalam kebudayaan yang merupakan sebuah penyederhanaan dari prkatek operasional tentang kebudayaan dalam kehidupan sehari-hari dan merupakan sebuah kebijakan sosial berupa penyususnan konseptual unsur-unsur dalam sebuah kebudayaan. Pada sifatnya, unsur kebudayaan memiliki sifat universal atau terdapat dalam semua kalangan elemen masyarakat dibelahan dunia, seperti manusia atau masyarakat primitif dan terpencil, masyarakat sederhana atau prapertanian, maupun masyarakat yang berkembang, mengindustri dan pasca industri yang sangat rumit serta canggih. Unsur dari sebuah kebudayaan dapat dipelajari pada pembelajaran IPS di sekolah dengan berbagai sub-unsur dari kebudayaan yang saling berkaitan dalam suatu susunan kebudayaan sosial yang meliputi beberapa hal dari unsur kebudayaan lainnya.

Dalam konteks pembelajaran Ilmu Pengetahuan Sosial memiliki hubungan kaitan yang erat dengan nilai sosial seperti yang ada pada kebudayaan. Pembelajaran IPS berbasis kebudyaan berhubungan erat dengan pembelajaran seperti indiginasi. Pembelajaran indiginasi merupakan pembelajaran yang memfokuskan peserta didik untuk kegiatan yang berbasis "learning from experience" yang memiliki arti bahwa pembelajaran IPS terintegrsi di sekolah dan di lingkungan sekitar berupa adat yang ada dilingkungan tersebut (Harrison, 2008). Selain itu model pembelajaran indiginasi yang digunakan pada pembelajaran IPS merupakan sebuah bentuk dari pembelajaran kontekstual yang berbasis kebudayaan (Komalasari, 2010:45).

Pembelajaran IPS yang berhubungan dengan wujud kebudayaan dan unsur kebudayaan merupakan sebuah rangkaian dalam pendidikan untuk menciptakan lingkungan pelajar dengan merancang sebuah perancangan pengalaman belajar yang menghubungkan budaya sebagai bagian sebuah proses pembelajaran yang di dapatkan di sekolah maupun di luar lingkungan sekolah seperti lingkungan masyarakat (Pannem, 2005:89). Selain itu, pembelajaran berbasis kebudayaan memiliki macam-macam pembelajaran yang berbeda seperti, belajar tentang budaya, belajar dengan budaya, dan belajar melalui budaya (Goldbreg, 2000). Adanya pembelajaran IPS 
berhubungan dengan kebudayaan akan menciptakan sebuah interaksi antara peserta didik dengan guru maupun antara peserta didik dengan individu lainnya. Dalam interaksi, perlu ada sebuah pedoman dan aturan yang dapat mengatur sikap individu mengenai apa yang seharusnya dilakukan dan apa yang tidak sepantasnya untuk dilakukan seseorang sebagai bentuk dari sebuah interaksi (Abbas, 2013).

\section{WUJUD KEBUDAYAAN DAN PEMBELAJARAN IPS}

Pengertian kata kebudayaan berasal dari kata budaya yang berasal dari bentuk jamak dari kata budidaya. Kata budaya sendiri memiliki beberapa arti yaitu, cinta, karsa, dan rasa. Kebudayaan juga merupakan sebuah gagasan, aktivitas, dan sebuah hasil karya dari manusia untuk diri masyarakat dalam sebuah kehidupan (Koentjaraningrat, 2009). Pada kebudayaan terdapat sebuah wujud kebudayaan yang berupakan sebuah tindakan yang memiliki pola bermacam-macam dari manusia dalam suatu lingkungan masyarakat. Pada wujud dari sebuah kebudayaan, manusia adalah komponen yang termasuk dalam kategori dari wujud kebudayaan. Hal tersebut dikarenakan manuia memiliki peranan yang dapat bersosialisai, berkomunikasi, serta bergaul diantara sesamanya yang kemudian membentuk sebauh interaksi yang akan membentuk kebudayaan. Berbeda dengan sistem budaya yang ada, kebudayaan pada wujudnya memiliki sifat yang berpola yang sangat gampang dilihat bahkan dapat didokumentasikan karena memiliki kenampakan yang nyata dalam perilaku kehidupan masyarakat. Oleh karena itu, pada penjelasan tersebut dapat diketahui bahwa kebudayaan memiliki erat dengan pembelajaran IPS karena menyangkut hal-hal sosial yang berhubungan anatara interasksi manusia dengan kebudayaan. Maka dari itu, pembelajaran IPS disekolah merupakan wujud nyata pembelajaran untuk mempetahakan wujud kebudayaan sebagai sebuah bentuk identitas bangsa.

Wujud kebudayaan juga dapat berupa sebuah hasil karya manusia berupa benda-benda

yang memiliki kaitan erat dengan kebudayaan. Wujud kebudayaan dapat juga disebut kebudayaan fisik karena wujud kebudayaan juga dapat berbentuk benda yang memerlukan keterangan yang banyak untuk mendefinisikan kebudayaan yang ada pada wujud benda yang bersifat kebudayaan. Hal tersebut dikarenakan seluruh total dari fisik dan totalitas kebudayaan memiliki sifat hasil fisik yang konkrit sehingga membuat wujud fisik dari benda tersebut memiliki ketiga hal wujud kebudayaan seperti jelas dilihat, dapat dilihat, serta dapat diraba. 
Selain itu, Koentjaraningrat mengemukakan wujud kebudayaan terbagi menjadi dalam tiga wujud kebudayaan yaitu, (1) Wujud kebudayaan sebagai suatu kompleks dari ide-ide, gagasan, nilai-nilai, norma-norma, dan peraturan. (2) Wujud kebudayaan sebagai suatu kompleks aktifitas serta tindakan yang memiliki pola dari manusia ke dalam lingkungan masyarakat. (3) Wujud kebudayaan sebagai benda-benda yang berbentuk fisik dan merupakan sebuah hasil dari karya manusia. Pada wujud kebudayaan tentu akan memiliki nilai-nilai kebudayaan yang berhubungan dengan tingkah laku manusia berupa ide, cita-cita atau gagasan daru suatu konsep mengenai baik atau buruknya etika seseorang yang berupa tradisi, moral, dan kebudayaan yang berlaku dalam kehidupan masyarakat (Sarbaini dan Fatimah, 2012:20).

Pembelajaran IPS di sekolah yang berkaitan dengan kebudayaan diharapkan agar semua peserta didik dapat memiliki pengetahuan serta wawasan mengenai berbagai konsep-konsep dasar dari Ilmu Sosial dan Humaniora untuk membentuk karakter pada peserta didik dalam mempertahankan atau memahami bentuk dari wujud kebudayaan. Pembelajaran IPS memiliki kepekaan dan kesadaran terhadap masalah sosial di lingkungan masyarakat serta memiliki keterampilan dalam mengkaji dan memecahkan masalah sosial seperti permasalahan sosial berupa wujud kebudayaan yang diklaim oleh bangsa lain dan lain sebagainya (Al Muchtar, 2007). Pembelajaran IPS menekankan pada aspek pendidikan yang diharapkan agar peserta didik dapat memiliki pemahaman mengenai konsep dan pengembangan terhadap sikap, nilai, moral dan keterampilan yang berdasarkan pada konsep yang telah diajarkan pada pembelajaran IPS.

Selain itu, pembelajaran IPS juga membahas hubungan antara manusia dengan lingkungan masyarakat yang memiliki wujud kebudayaan yang berbeda-beda dan membuat peserta didik akan dihadapkan pada berbagai permasalahan daari lingkungan serta harus memahami berbagai kebudayaan yang ada pada setiap lingkungannya (Buchari, 2015).

\section{UNSUR KEBUDAYAAN DAN PEMBELAJARAN IPS}

Unsur-unsur kebudayaan adalah sebuah unsur dari kebudayaan yang memiliki peranan penting untuk memahami beberapa unsur dari kebudayaan yang ada di lingkungan masyarakat. Unsur kebudayaan yang ditemukan pada bangsa di dunia memiliki sistem kebudayaan yang sederhana. Hal tersebut dapat ditemukan pada semua masyarakat pedesaan yang kompleks seperti masyarakat perkotaan. Unsur kebudayaan secara universal terbagi menjadi tujuh unsur 
yaitu, sistem dan organisasi sosial, sistem religi dan upacara keagamaan, sistem mata pencaharian, sistem ilmu pengetahuan, sistem teknologi dan peralatan, bahasa, serta kesenian. Unsur-unsur kebudayaan tersebut dirinci dan dipelajari dengan kategori sub-unsur yang saling berkaitan dengan pembelajaran IPS yang berbasis sistem kebudayaan sosial dan meliputi semua hal yang akan selalu berkaitan.

Unsur-unsur kebudayaan yang bersifat universal tersebut menjadi sebuah kesatuan dan saling berkaitan dalam lingkungan masyarakat. Hal tersebut dikarenakan unsur-unsur kebudayaan dapat ditemukan di dalam kebudayaan semua bangsa dan negara di dunia. Selain itu, secara universalnya, unsur kebudayaan memiliki tujuh unsur-unsur kebudayaan yang memiliki keterkaitan pada kehidupan masyarakat. Adapun penjelasan ketujuh unsur-unsur kebudayaan tersebut yaitu, Pertama, sistem dan organisasi sosial memiliki arti dibutuhkan manusia karena manusia mempunyai kecenderungan dalam berkelompok. Kedua, sistem religi dan upacara keagamaan merupakan sistem aliran kepercayaan yang memiliki hubungan dengan penciptaNya. Ketiga, sistem mata pencaharian merupakan sistem kebutuhan manusia pada sistem produksi, distribusi, dan konsumsi. Keempat, sistem ilmu pengetahuan meliputi beberapa ruang imu pengetahuan yang membahas mengenai lingkungan alam sekitar berupa flora dan fauna, waktu, ruang dan bilangan, sifat-sifat dan tingkah laku sesama manusia, hingga tubuh manusia. Kelima, sistem teknologi dan peralatan, kedua hal tersebut berhubungan pada sebuah cara atau teknik dalam memproduksi sebuah teknologi yang dijadikan peralatan, lalu kemudian menggunakan teknologi dan peralatan tersebut untuk berbagai kepentingan, serta memelihara berbagai peralatan dan perlengkapan yang digunakan dalam kehidupan. Keenam, bahasa merupakan sistem perlambangan dari sebuah lisan yang dimiliki manusia berupa lisan maupun tertulis untuk berkomunikasi satu sama lain. Ketujuh, kesenian merupakan sebuah sarana yang digunakan manusia dalam melakukan kebebasan dalam membuat kreativitasnya yang berdasar dari unsur keindahan yang dimiliki dari dalam lubuk hati mausia. Dari ketujuh makna unsurunsur kebudayaan tersebut, dapat disimpulkan bahwasanya setiap unsur-unsur tersebut merupakan sebuah bagian yang selalu ada dalam bermasyarakat.

Dari beberapa analisa penjelasan mengenai unsur-unsur kebudayaan yang bersifat universal tersebut menjadikan pembelajaran IPS dimanfaatkan untuk mengkaji beberapa permasalahan yang berhubungan dengan kebudayaan. Hal tersebut penting karena memberikan 
pemecahan masalah yang logis dan bisa digunakan untuk menyelesaikan beberapa masalah yang ada dilingkungan sosial masyarakat. Selain itu, penggunaan unsur-unsur kebudayaan pada pembelajaran IPS akan memberikan pemahaman kepada peserta didik untuk dapat membedakan bagaimana unsur kebudayaan yang bisa digunakan dan bagaimana unsur kebudayaan yang tidak dapat digunakan.

\section{SIMPULAN}

Pembelajaran IPS bebasis kebudayaan yang mengacu pada wujud kebudayaan dan unsur-unsur kebudayaan meberikan pengetahun secara efektif dan efesien kepada peserta didik. Selain itu, penggunaan materi kebudayaan pada pembelajaran IPS dapat memberikan pengetahuan,

pemahaman, dan bagaimana cara untuk menyelesaikan permasalahan untuk kehidupan peserta didik. Hal tersebut dilakukan karena peserta didik akan dihadapkan dengan keadaan lingkungan sosial yang bermacam-macam sehingga harus memiliki pemahaman mengenai kebudayaan yang ada pada setiap lingkungan di masyarakat. Ketika peserta didik menghadapi permasalahan di lingkungannya, peserta didik yang sudah diberikan pembelajaran mengenai pemecahan masalah, dapa melakukan penyelesaian masalah dengan beberapa solusi yang sudah diajarkan pengajar kepada peserta didik. Untuk itu, pada wujud kebudayaan diharapkan peserta didik dapat memahami bagaimana wujud dari kebudayaan yang sebenarnya. Kemudian untuk unsur-unsur kebudayaan, peserta didik harus bisa memahami unsur-unsur kebudayaan yang bersifat universal untuk dijadikan acuan dalam menajalani kehidupan di lingkungan sekolah maupun di lingkungan yang berada pada luar sekolah. Adapun ketujuh unsur kebudayaan yang bersifat universal adalah sebagai berikut ini yaitu, sistem dan organisasi sosial, sistem religi dan upacara keagamaan, sistem mata pencaharian, sistem ilmu pengetahuan, sistem teknologi dan peralatan, bahasa, serta kesenian.

\section{REFERENSI}

Abbas, E. W. (2015). Pendidikan IPS Berbasis Kearifan Lokal. WAHANA Jaya Abadi.

Antosa, Z. (2017, September). REVITALISASI NILAI BUDAYA TRADISIONAL MELALUI PEMBELAJARAN SENI DENGAN PENDEKATAN MULITIKULTUR. In CONFERENCE PROCEEDING ICETS 2016 (p. 412). 
Dan, P. D. D. S. P. (2017). Kebudayaan,”. Statistik PAUD, 2018.

Irwan, W., Mahyudi, J., \& Sukri, M. (2018). Unsur-Unsur Kebudayaan Dalam Teks Nggahi Dana Pada Masyarakat Dompu: Suatu Pendekatan Arketipel-Pragmatik. LINGUA: Jurnal Bahasa, Sastra, dan Pengajarannya, 15(2), 131-146.

Komalasari, K., \& Maftuh, B. (2014). Model Pembelajaran Indiginasi dalam IPS untuk pengembangan Wawasan Multikultur Mahasiswa. Edusentri, 1(1), 39-53.

Maryani, E., \& Yani, A. (2014). Kearifan Lokal Masyarakar Sunda dalam Memitigasi Bencana dan Aplikasinya Sebagai Sumber Pembelajaran IPS Berbasis Nilai. Jurnal Penelitian Pendidikan, 14(2).

Miharja, D. (2016). Wujud Kebudayaan Masyarakat Adat Cikondang dalam Melestarikan Lingkungan. Program Studi Agama-Agama UIN Sunan Gunung Djati Bandung, 1(1), 5261.

Syaharuddin, S., Hidayat Putra, M. A., \& Susanto, H. (2019). Nilai Budaya Manyambang Masyarakat Desa Lok Baintan dalam Sebagai Sumber Belajar IPS. 